Volume 9

Issue 2 Time, Movement, and Space: Genocide

Studies and Indigenous Peoples

Article 15

$10-2015$

\title{
Film Review: The Act of Killing
}

Annie E. Pohlman

University of Queensland

Follow this and additional works at: https://digitalcommons.usf.edu/gsp

\section{Recommended Citation}

Pohlman, Annie E. (2015) "Film Review: The Act of Killing," Genocide Studies and Prevention: An

International Journal: Vol. 9: Iss. 2: 131-134.

DOI:

http://dx.doi.org/10.5038/1911-9933.9.2.1356

Available at: https://digitalcommons.usf.edu/gsp/vol9/iss2/15

This Film Review is brought to you for free and open access by the Open Access Journals at Digital Commons @ University of South Florida. It has been accepted for inclusion in Genocide Studies and Prevention: An International Journal by an authorized editor of Digital Commons @ University of South Florida. For more information, please contact digitalcommons@usf.edu. 
Film Review: The Act of Killing (2012)

\section{Annie E. Pohlman \\ University of Queensland \\ Brisbane, Australia}

The Act of Killing - Film Review

Director: Joshua Oppenheimer

Denmark/Norway/UK, 2012

Reviewed by Annie Pohlman

University of Queensland

Brisbane, Australia

Joshua Oppenheimer's The Act of Killing (TAOK) was released three years ago. ${ }^{1}$ This documentary about killers, their actions fifty years ago and the impunity they have enjoyed ever since has been almost universally acclaimed: it was nominated for an Academy Award in 2014 and has won more than 70 international awards including a BAFTA (2014) and a European Film Award (2013). Though certainly not without controversy, this acclaim garnered from audiences and critics around the world is well-deserved. ${ }^{2}$ It is a rare film indeed which can force such physical reactions in its audience. As with so many who have seen this film over the last few years, TAOK made me laugh, sickened me and made the hairs on the back of my neck stand on end, repeatedly. In so many ways, I applaud this film. My applause comes both from a personal perspective, in appreciation of the tremendous achievements of this documentary, and from that of an academic whose own research overlaps very closely with the content and issues raised in TAOK.

On a personal level, Oppenheimer's film asks us as individuals to look more closely, and more carefully, at what perpetrators do, feel, and how they justify their actions to themselves. Having seen the film several times now, I am discomforted, but strangely not surprised or horrified, by how close I feel to the perpetrators of mass violence by the end of the film. They are at once repulsive and compelling, gregarious and horrifying. On a personal level, I cannot help but wonder if this is what the film is asking: are we all capable of such violence? This is probably not a question I ever want to answer.

My reactions to watching Oppenheimer's TAOK also stem from my own work over the past decade and a half. As a researcher of the mass killings and mass political detentions of Communist sympathizers during the mid-1960s in Indonesia, I have interviewed more than 200 survivors of these mass atrocities, most of them women who were either witnesses to the killings or who survived the detention camps. An estimated 500,000 men, women and children were killed in 19651966, but a further one million people were rounded up and held in these detention camps for months or years where torture, starvation and forced labour were common.

The protagonists of Oppenheimer's film are the killers themselves; the main character, Anwar Congo, and his assorted unsavoury henchmen are self-described preman (gangsters/criminals) who gained power through their cooperation with the Indonesian military in detaining, torturing and murdering members and sympathisers of the Indonesian Communist Party (PKI, Partai Komunis Indonesia). These old men act out their past acts of violence - garrotting their victims, beating their prisoners, attacking and burning down villages - with pleasure. The elation of being given the chance to re-enact scenes from the glory days of their youth is apparent in their voices and in their eyes: the close-up and personal focus of Oppenheimer's film lens forcing us to stand and witness this elation at a very uncomfortable and intimate distance.

As a researcher of this period of mass atrocities in Indonesian history, I am truly impressed not only that Oppenheimer and his team were able to convince perpetrators of the mass killings to speak with him about their actions (and that they did so on film), but that he was able to convince so many perpetrators to participate. As the director has stated, Anwar Congo was the 
$41^{\text {st }}$ perpetrator interviewed by him. ${ }^{3}$ While the military regime which rose to power during the massacres, General Suharto's New Order (1966-1998), may have ended nearly twenty years ago, the stigmatization and harassment of survivors and the celebration of the killings have continued to affect how these events are retold and remembered (or forgotten, rather) in Indonesia. Carrying out research on 1965 is difficult, sensitive and sometimes dangerous work, particularly for the men and women survivors, and their families, who make the choice to speak about their experiences. As a researcher of 1965, therefore, I cannot but applaud the dedication and skill that have gone into making this masterful anti-documentary. And I hope that Oppenheimer and his team will make use of their other interview materials with perpetrators, so that we may learn more about the motivations and actions of those who took part in capturing, torturing and murdering so many of their fellow Indonesians.

TAOK has revitalized, certainly among international circles, attention to this dark part of Indonesian history which has gone mostly unnoticed on the world stage. Oppenheimer and his (mostly Indonesian) team deserve the long list of festival and critics' awards that they have received over the past three years. The film itself has been taken up in many ways by different interest groups: by human rights groups to draw international attention to the killings; by some academic and activist circles to lobby the Indonesian government to acknowledge and redress the killings (e.g. Say Sorry for 65 campaign coordinated by TAPOL); ; and by others to draw attention to the role of some Western powers in supporting, and even directly financing, the massacres. ${ }^{5}$

Inside Indonesia, the reactions have been varied; from hot debates in the nation's top media outlets, to the occasional public statements by government officials (some supportive of looking into the past, others justifying the killings $)^{6}$, to blatant disinterest. Although not officially banned in Indonesia, the film did not receive an official release and has therefore only been screened at underground and select public venues. ${ }^{7}$ In the media debates, there have been complaints that the film was made by foreigners (the film crew, including one of the co-directors, were mostly Indonesian nationals) and that, as such, it misinterprets or misrepresents this episode in Indonesian history. Personally, I would say that the history of The Act of Killing will be ongoing, at least for the next few years. I do not think that this film will fade away, either internationally or domestically in Indonesia. Once you see TAOK, it sticks too firmly in your mind. This, more than anything else the film may hope to achieve, will ensure that it will continue to be viewed, and passed on, in the years to come.

For me, the strength of this film lies both in the horrors which it portrays and in those horrors which it does not. The first time I saw TAOK, I was annoyed and indignant because I felt that there were so many people missing from the film: the victims, their families, and all of the dead. The second time I watched the film, however, I started to see how all three were ever-present.

In the scene where Anwar Congo and one of his followers take Oppenheimer to the shop rooftop where he acts out his method of garrotting his victims, he alludes to how many ghosts there must be there. Certainly Anwar's steps are followed by the dead. While he may do what he can to ignore them during the day, at night he feels them in his dreams as he sweats and turns in his bed. Anwar's neighbor, Suryono, tells the group of former killers during a break in filming how his step-father was taken away and butchered in the night, his body left out like that of an animal to rot. As we watch Suryono only minutes later as he plays out the part of a victim of torture, we cannot help but feel that his step-father, and so many others tortured and killed in the detention centres which stretched across the archipelago, are in the room with us. And, indeed, the dead are felt at so many points throughout the film: in my annoyance, I had simply missed them the first time I watched the film.

The omission of victims' perspectives and that of their families was a deliberate choice by Oppenheimer and his team in making this documentary; as University of Sydney academic Vannessa Hearman has written, "The exclusion of victims from TAOK is therefore also a comment on the invisibility of victims in Indonesia." 8 The victims and the dead are not present in the film physically, but they are certainly a seething presence, dominating the film in so many ways.

The same is true of the portrayal of sexual violence in TAOK. As the focus of my research on mass violence of 1965-1966 has been on sexual violence against women and girls during this period, when I first watched the film, I was taken aback. Sexual violence was pervasive during the 
killings and in the detention camps, so I wondered why wasn't this made clear in the film? Once again, it was only in my second viewing that I realised that it was.

At several points in the film, we see the blatant and casual sexual harassment and objectification of young women: examples include the dancing girls who should dance "more hot" out of the surreal giant fish and the leader of the Pancasila Youth, Yapto Surjosumarno, and his treatment of his golf caddy, a young woman who asks for his autograph, and his laughter at a joke about a girl who performs oral sex on numerous men because she "wants it." When watching this film for the third time, and for the first time with a group of people at a screening of the film on a university campus in Australia, these moments produced laughter from the audience. In her analysis of the film, Dutch researcher Saskia E. Wieringa discusses themes of sexualized violence and the demonisation of Communist women, such as in the portrayal of the character Aminah-the supposedly mad Communist woman played by Anwar's sidekick, the fat Herman Koto in drag. ${ }^{9}$ Again, in the scenes in which Herman plays Aminah, with great comic effect, the audience laughed and so did I. The misogynist treatment and depictions of women in these ways, however, are not coincidental nor are they merely meant to provide moments of light hilarity to break up the more "serious" and confronting portrayals of violence; they are fundamental to understanding the widespread nature of sexual violence.

For me, the very short, seemingly aside scenes which touch on the issue of sexual violence are those which also speak to the pervasive nature of this violence. The most obvious is the scene which shows Safit Pardede, a local paramilitary leader and former killer during 1965 who joins Anwar Congo and his team in creating their film. Safit sits off to the side, surrounded by other men who are taking a break from their re-enactment of the massacre of a village. The men laugh and catcall as Safit tells them about raping women during the killings in 1965. If they were pretty, he'd "rape them all." He boasts that raping fourteen-year-old girls was the "best", and how it would be heaven for him, but hell for them. The laugher, Safit's description of "fucking everything" he could because they were "the law back then" reveals, in these short moments, both the widespread nature of sexual violence against women and girls during the mass violence of 1965 and the impunity with which this violence was perpetrated. Shortly after this scene, we see the re-enactment of the massacre of a village, in which the men, women and children who were hired to act as the victims re-create, in a fiery and blackened nightmare scene, the destruction of human life en masse. You see the victims being dragged into piles of human flesh or being taken out into the surrounding forest, and you see the women being grabbed, their clothes pulled and torn. After the killers yell, "Cut! Cut! Cut!," the children are inconsolable and one women is clearly overwhelmed and needs to be revived. Once again, these short scenes reveal much by leaving out the portrayal of sexual violence perpetrated in 1965.

Lastly, we must remember that TAOK is the first of two documentaries. The first forces us to confront the killers. The second in the series is The Look of Silence, released in 2014, and is about the survivors. Specifically, it tells the story of a family of survivors and their interactions with the men who killed their son. As in TAOK, this second documentary speaks strongly to the long and entrenched history impunity in Indonesia, showing the comfortable lives of killers and the mostly silent lives of survivors. Taken together, the two films force us to confront, in a personal and heartbreaking way, the reality of life for survivors and perpetrators who live side-by-side in the very places where horrific violence was carried out.

Oppenheimer's two documentaries have achieved much, and it is my hope that they will continue to draw attention to the killings of 1965 and the fifty years of impunity which have followed. These films captivate and repulse, so that you cannot look away. The enduring trauma of survivors and communities, the lack of justice for so many dead, and the ongoing impunity for those who carried out this violence are held up as a mirror to the participants of these films and to us. The Act of Killing and The Look of Silence (also reviewed in this journal) are not stories of redemption, or reconciliation, or hope. Because the history of 1965 in Indonesia, so far, promises us none of these things.

Title of the Film: The Act of Killing; Director: Joshua Oppenheimer; Co-Directors: Christine Cynn, Anonymous; Producers: Signe Byrge Sørensen, Anonymous, Anne Köhncke, Werner Herzog, 
Errol Morris, Joram ten Brink; With: Anwar Congo, Herman Koto, Syamsul Arifin, Adi Zulkadry; Cinematography: Anonymous, Carlos Arango De Montis, Lars Skree; Film Editors: Nils Pagh Andersen, Charlotte Munch Bengtsen, Ariadna Fatjó-Vilas, Janus Billeskov Jansen, Mariko Montpetit; Countries: Denmark/Norway/UK; Year of Release: 2012; Production Company: Final Cut for Real. Duration: 115 minutes.

\section{Endnotes}

1 Parts of this review appeared in Annie Pohlman, "The Absence of Violence in The Act of Killing," Protection Gateway Blog, 19 March 2014, online at http://protectiongateway.com/2014/03/19/the-absence-of-violencein-the-act-of-killing/ (viewed 28 May 2015).

2 Though generally acclaimed by critics and audiences, there have been condemnations of the film as well. See, for example, Nick Fraser, "The Act of Killing: Don't Give an Oscar to this Snuff Movie," The Guardian, 23 February 2014, online at http://www.theguardian.comcommentisfree/2014/feb/23/act-of-killing-dont-giveoscar-snuff-movie-indonesia (viewed 3 July 2015).

3 See Joshua Oppenheimer's discussion about how the documentary was made: Joshua Oppenheimer, "The Act of Killing has Helped Indonesia Reassess its Past and Present," The Guardian, 26 February 2014, online at http://www.theguardian.com/commentisfree/2014/feb/25/the-act-of-killing-indonesia-past-present-1965genocide (viewed on 10 June 2015).

4 The TAPOL "Minta Maaf! Say Sorry for 65" campaign can be found at: http://tapol.org/saysorryfor65 (viewed on 8 June 2015).

5 Brad Simpson, "It's Our Act of Killing, Too," The Nation, 28 February 2014, www.thenation.com/ article/178592/its-our-act-of-killing-too\# (viewed on 30 May 2015).

6 For some public statements made in regard to the killings, see James Balowski, "Yudhoyono Government Says 1965 Murders 'Saved' Indonesia," 22 October 2012, online at http://directaction.org.au/yudhoyono government says 1965 murders saved indonesia (viewed 12 June 2015).

7 The film was made available to download free of charge to those in Indonesia at the end of September 2013 via the website: www.theactofkilling.com.

8 Vannessa Hearman, “'Missing Victims' of the 1965-66 Violence in Indonesia: Representing Impunity Onscreen in The Act of Killing," Critical Asian Studies 46, 1 (2014): 171-75.

9 See Saskia E. Wieringa, "Sexual Politics as a Justification for Mass Murder in The Act of Killing," Critical Asian Studies 46, 1 (2014): 195-99. 